DOI:

Анжеліка Любас, викладач кафедри іноземних мов та військового перекладу Національної академії сухопутних військ імені гетьмана Петра Сагайдачного

\title{
ОРГАНІЗАЦЙНІ АСПЕКТИ ФОРМУВАННЯ МІЖКУЛЬТУРНӦ̈ КОМПЕТЕНТНОСТІ МАЙБУТНІХ ФАХІВЦІВ БОЙОВОГО ТА ОПЕРАТИВНОГО ЗАБЕЗПЕЧЕННЯ ЗА КОРДОНОМ
}

У статті висвітлено організаційні аспекти формування міжкультурної компетентності майбутніх фахівиів бойового та оперативного забезпечення за кордоном. Проаналізовано основні форми, методи та засоби навчання ичих фахівців. Проблема формування міжкультурной компетентності майбутніх військовослужбовиів є актуальною у їхній професійній підготовиі, не тільки в Украйні, а у прочесі підготовки ичих спеціалістів інших країн. Використано метод аналізу та узагальнення для теоретичного обгрунтування організаційних аспектів формування міжкультурної компетентності згаданих фахівиів.

Ключові слова: фахівці бойового та оперативного забезпечення; форми організації навчання; методи навчання; засоби навчання.

Jim. 22.

Anzhelika Lyubas, Lecturer of the Foreign Languages and Military Translation Department National Academy of Ground Forces named after Hetman Petro Sahaydachniy

\section{ORGANIZATIONALASPECTS OF FORMING INTERCULTURAL COMPETENCE OF FUTURE SPECIALISTS OF COMBAT AND OPERATIONAL SUPPORT ABROAD}

The article deals with the organizational aspects of formation of intercultural competence of future specialists of combat and operational support abroad. The basic forms, methods and teaching techniques of these specialists are analyzed. The problem of formation of intercultural competence of future servicemen is relevant in their professional training, not only in Ukraine, but in the process of training these specialists from other countries. The method of analysis and generalization was used for theoretical substantiation of organizational aspects of formation of intercultural competence of mentioned specialists. At the present stage, there is widespread cooperation between military experts from NATO member countries within peacekeeping missions and joint exercises. The level of intercultural competence of future military specialists in foreign countries should be high. Servicemen must have certain ability, knowledge and skills. For this purpose, certain methods of teaching, forms of organization and teaching techniques are used in the educational process abroad. So, intercultural competence of future specialists of combat and operational support is defined as a set of knowledge, skills and abilities that help them to conduct effectively their professional activities and communicate freely with partners of other cultures under conditions of international integration and on the basis of understanding and respect. Intercultural competence is a significant component of the professional competence of future specialists of combat operational support, because it is based on a set of key, linguistic, sociocultural and discursive competencies. The key characteristics of intercultural competence are: multifunctionality, supersubjectiveness, interdisciplinarity, multidimensionality, consideration of diverse thought processes and intellectual skills. Components of intercultural competence of future specialists of combat operational support are: language skills: lexical, grammatical, spelling, etc.; multicultural knowledge; cognitive knowledge and skills; ability to analyze the speech situation; the ability to control their actions during communication, in particular, the ability to overcome fear; etc.

Keywords: specialists of combat and operational support; forms of organization of education; teaching methods; teaching techniques.

П Гостановка проблеми. На сучасному етапі спостерігається широка співпраця військових спеціалістів країнучасниць НАТО у рамках миротворчих місій та проведенні спільних навчань. Рівень міжкультурної компетентності майбутніх військових спеціалістів за кордоном має бути на рівні світових стандартів. Військовослужбовці повинні володіти певними уміннями, знаннями та навичками. Для цього за кордоном у навчальному процесі застосовуються певні методи, форми організації та засоби навчання.
Аналіз останніх досліджень і публікацій. Багато дослідників зосереджують свою увагу на організаційних аспектах формування міжкультурної компетентності майбутніх фахівців бойового та оперативного забезпечення за кордоном.

У працях О. Бойка, Л. Снігур, М. Варія, М. Коваля та ін. розглянуто питання стосовно навчання майбутніх військовослужбовців, форм організації, методів та засобів навчання за кордоном.

Дослідження В. Чайки, I. Малафіїка, В. Ягупова, Т. Кравчини, 3. Курлянда зосереджені на основних 


\section{ОРГАНІЗАЦЙНІ АСПЕКТИ ФОРМУВАННЯ МГЖКУЛЬТУРНОӤ КОМПЕТЕНТНОСТІ МАЙБУТНІХ ФАХІВЦІВ БОЙОВОГОТА ОПЕРАТИВНОГОЗАБЕЗПЕЧЕННЯ ЗА КОРДОНОМ}

формах організації, методах та засобах навчання.

Метою статті $€$ аналіз організаційних аспектів формування міжкультурної компетентності майбутніх фахівців бойового та оперативного забезпечення за кордоном.

Виклад основного матеріалу. Навчання військових за кордоном спрямоване на оволодіння військово-професійними навичками. Більше уваги приділяється практиці, створена система стимулювання процесу навчання та використовується нова навчально-методична література. На академічну програму підготовки надається 70\% навчального часу. В межах академічної програми вивчається прикладна воєнна психологія та педагогіка. Ця програма складається з 2 блоків: основна програма (складається з обов'язкових дисциплін) та елективна програма (складається 3 курсу обмеженого вибору, які пропонують кафедри відповідно до сфер спеціалізації), також вона включає факультативні курси, які обираються курсантами відповідно до своїх інтересів. На військову програму відводиться $20 \%$ навчального часу, на фізичну 10\% [3, 288 - 291].

До прикладу, у військовій академії Вест Поінт (West Point) кожен курсант повинен пройти тридцять один навчальний курс, що входить до навчального плану підготовки майбутніх фахівців. За період навчання в академії курсанти, окрім основних та спеціальних навчальних дисциплін, повинні пройти щонайменше дев'ять предметів за вибором. В кінці другого курсу всі майбутні військовослужбовці обирають спеціальність і зобов'язані прослухати від десяти до тринадцяти факультативних курсів. Альтернативним вибором курсантів $є$ вибір сфери навчання, обов'язковою вимогою якого $\epsilon$ вивчення дев'яти факультативних курсів. Метою навчальних програм підготовки майбутніх військовослужбовців $€$ розвиток відповідних якостей характеру, інтелекту та фізичної компетентності, необхідних офіцерам армії, які на різних стадіях своєї кар'єри повинні бути готовими керувати найменшим бойовим підрозділом або консультувати найвищого державного службовця. Для досягнення цієї мети навчальний план доповнюється військовою та фізичною підготовкою. Фізична підготовка майбутніх військовослужбовців у академії триває протягом усього навчального року. У рамках програми фізичної підготовки курсанти слухають лекції 3 етики та моралі. Навчальні програми підготовки майбутніх військовослужбовців у академії забезпечують належний рівень сформованості у фахівців професійної компетентності та їі

складових, зокрема міжкультурної компетентності, що слугують надійною основою для подальшого професійного розвитку таких фахівців [22].

Стосовно форм організації навчання у військових навчальних закладах, за кордоном виділяють наступні: лекції, інтегровані лекційнопрактичні заняття, семінари, практичні заняття, самостійна робота, спеціальна підготовка, психологічна підготовка, курси підвищення кваліфікації, командно-штабна підготовка, мовна підготовка, он лайн навчання та ін. [2, 293].

Щодо практичної підготовки в арміях США, Великої Британії та Канади виділяють такі форми навчання: індивідуальна та колективна. Індивідуальна форма включає навчання під час виконання професійних обов'язків, а також підготовку до виконання призначених завдань. Колективна форма має на меті підтримати оперативну готовність військових частин та підрозділів [2, 327 - 328].

У вищих військових навчальних закладах США, Канади, Великобританії викладачі у процесі проведення навчальних занять найчастіше використовують такі методи навчання: пояснювально-ілюстративні, методи проблемного викладу, частково-пошукові (проблемнопошукові), метод проектів, дидактичні ігри (ситуативні, рольові, ділові, інтелектуальні (“брейн стормінг”, тестування), метод розігрування ролей, кейси, метод Каллана, метод тандему, PRESформула, метод Тейєра, метод навчання по станціям тощо [11, 2].

Пояснювально-ілюстративні методи навчання полягають у поясненні інформації з використанням різних засобів, і зосереджені на засвоєнні студентами навчального матеріалу $[19,5]$. До них входять: розповідь, пояснення, демонстрація, робота з підручником, графічна візуалізація, медіа, тощо.

Розповідь - викладення матеріалу у пояснювальній формі або у формі оповіді [21, 326]. Цей метод застосовується під час занять із бойової та гуманітарної підготовки, а також під час вивчення принципів дій бойової техніки та зброї [2, 260]. Пояснення - послідовний, чіткий, логічний виклад матеріалу, принципів чи схем, які поєднується разом з демонстрацією приладів, схем, частин зброї тощо[4, 343]. Робота з підручником самостійна робота студентів 3 текстами, це допоможе зрозуміти їм та закріпити навчальний матеріал [16, 123 - 124]. Графічна візуалізація сприймання певного обсягу інформації 3 використанням схем, картин, діаграм тощо. Медіа - передача візуальної інформації, зокрема відео 3 використанням технічних засобів навчання. 


\section{ОРГАНІЗАЦІЙНІ АСПЕКТИФОРМУВАННЯ МГЖКУЛЬТУРНОЇ КОМПЕТЕНТНОСТІ МАЙБУТНІХ ФАХІВЦІВ БОЙОВОГО ТА ОПЕРАТИВНОГОЗАБЕЗПЕЧЕННЯ ЗА КОРДОНОМ}

Методи проблемного викладу спрямовані на представлення викладачем певної проблеми та пошук шляхів іiі розв'язання у співпраці зі студентами. Характерними ознаками методів проблемного викладу є такі:1) студентам не пропонують знання у “готовому” вигляді; 2) викладач показує шлях дослідження проблеми і розв'язує iї від початку до кінця; 3) студенти спостерігають за процесом та навчаються розв'язувати проблемні завдання. Методи проблемного викладу застосовується під час проблемної розповіді, проблемно-пошукової бесіди, лекції тощо $[19,2]$.

Частково-пошукові методи (проблемнопошукові) - методи навчання, під час яких викладач допомагає студентам оволодіти лише частиною знань, іншу частину студенти здобувають самостійно шляхом розв'язання даних проблем [19], зокрема у процесі виконання проектів. Дані методи допомагають студентам самостійно вчитися “бачити проблему”, виділяти iii 3 - поміж інших, осмислити та встановити послідовність іiі вирішення та розробити свою логіку розвгязання проблеми. Частково-пошукові методи розвивають самостійну та розумову діяльність у студентів, готують їх до цілісного бачення всього шляху пошуку проблеми [10]. Навчальний матеріал за цим методом викладається у процесі евристичної бесіди, творчої вправи, лабораторної роботи тощо [19].

Метод проектів доволі часто застосовується за кордоном, мета якого навчити спілкуванню іноземними мовами, враховуючи інтереси та вік тих, хто навчається. Проектна робота поділяється на 2 категорії: спонтанна (відбувається без підготовки протягом 10-15 хв.) та довгострокова (студенти самостійно готують проекти та захищають). Цей метод допомагає розвивати монологічне мовлення та засвоювати різноманітну лексику [15].

Дидактичні ігри використовуються у навчанні курсантів з метою моделювання справжніх механізмів та процесів військово-професійної діяльності. За допомогою цих ігор курсанти навчаються техніки досягнення успіху під час проходження бойових дій. Вони проводяться у формі військово-педагогічних та військовопрофесійних ігор [2, 279]. Згадані методи поділяються на ситуативні, рольові, ділові, інтелектуальні. У процесі ділової гри створюється комунікативна ситуація, наближена до реальних подій. У ній студенти отримують ролі та спілкуються іноземною мовою [12]. За рахунок наближення до умов професійної діяльності курсантів, підвищення мотивації, активізації когнітивної сфери (мислення, концентрація уваги, пам'ять) значно зростає ефективність навчального процесу $[9,47]$. В межах методу дидактичних ігор вирізняють метод розігрування ролей. Цей метод належить до ігрових методів навчання. Метод розігрування ролей формує у військовослужбовців мотивацію до участі у ситуаціях професійноорієнтованого спілкування, уміння приймати відповідні рішення, розуміти мотиви комунікативних дій інших учасників спілкування, зокрема й міжкультурного спілкування [2, 279].

Кейс метод передбачає поглиблене вивчення конкретної ситуації професійно-орієнтованого спілкування у контексті моделювання виконання завдань бойового та оперативного забезпечення в умовах, наближених до бойових дій, які як правило виникають і вирішуються у проблематично-стресових ситуаціях. Іншими словами “кейс" - це події, які відбувались у певній сфері діяльності у реальному житті [1]. Обговорюючи ці випадки, студенти мають змогу проявити креативний підхід до прийняття рішень. Це впливає на розвиток особистісних та професійних якостей [20,2].

В умовах розвитку співпраці та освоєння методів роботи військових спеціалістів країнучасниць НАТО та співпраці України в рамках миротворчих місій та при проведенні військових навчань виникають нові критерії рівня міжкультурної компетентності до особистості фахівців бойового та оперативного забезпечення, які в сучасних умовах повинні володіти відповідними знаннями, навичками та вміннями. Створенню таких умов сприяє застосування кейс методу. При застосуванні цього методу відбувається розвиток таких навичок як: читання, говоріння, аналіз тексту, запам' ятовування нових лексичних одиниць, спільне обговорення ситуацій та індивідуальне формулювання висновків. Процес створення кейсів включає етапи: 1) формулювання цілей кейсу; 2) обрання теми та визначення проблематики;3) аналіз інформації по даній ситуації; 4) написання текст; 5) розробка завдання до ситуації та метод контролю; 6) запровадження кейса у навчальному процесі. Застосування кейс-методу допомагає у підвищенні ефективності професійноорієнтованого навчання, сприяє самостійності студентів до прийняття рішень, тим самим наближаючи їх до реальних обставин при виконанні професійних обов'язків [1].

Одним із новітніх методів викладання вважається метод Калана, який створює мовне середовище для особи, що навчається та залучає iii до спілкування, а також формує мовні та 


\section{ОРГАНІЗАЦЙНІ АСПЕКТИ ФОРМУВАННЯ МГЖКУЛЬТУРНОӤ КОМПЕТЕНТНОСТІ МАЙБУТНІХ ФАХІВЦІВ БОЙОВОГОТА ОПЕРАТИВНОГОЗАБЕЗПЕЧЕННЯ ЗА КОРДОНОМ}

мовленнєві навички [12]. Заняття за даним методом поєднує дві основні ідеї: розвиток швидкості мислення та постійна взаємодія між викладачем та студентами, з метою отримання навичок спілкування іноземною мовою. Метод Каллана використовується у таких програмах: Callan Method, Callan for Business ta Callan for Kids [22]. Метод Каллана включає чотири основні принципи:1) цілеспрямована бесіда; 2) читання 3 викладачем; 3) диктант; 4) введення нової лексики [22].

Структура заняття за цим методом така: 1)повторення пройденого матеріалу, який вивчався протягом 6 занять;2)невелика перерва; 3)перехід до нового матеріалу, який вивчатиметься протягом наступних 6 занять.

Метод Каллана акцентує на комунікативній діяльності студентів. На заняттях із застосуванням методу Каллана студенти вивчають нові слова та граматику англійської мови в структурованій послідовності 3 систематичним закріпленням пройденого матеріалу. Викладач, у свою чергу, постійно говорить англійською протягом всього заняття, задає питання двічі, тому що швидкість мовлення викладача висока і не всі студенти розуміють питання $з$ першого разу; говорить швидко, щоб студенти звикли до мови, наближеної до мови носіїв [6].

Метод тандему часто застосовується на заняттях іноземних мов у процесі роботи у парах, за умови, що один із учасників пари є носієм мови, що вивчається. Таким чином, носій мови виконує роль співрозмовника [12]. Головною метою даного методу є формування іншомовної комунікативної компетентності у студентів, тобто у них має формуватись здатність і готовність здійснювати міжособистісне і міжкультурне спілкування 3 носіями мови $[8,2]$. Навчання за цим методом вважається одним 3 найбільш перспективних напрямків 3 використанням сучасних технологій, які спрямовані на самонавчання та саморозвиток. Навчальний план виходить $з$ потреб та зацікавленості партнерів, які мають можливість використовувати мову, що вивчають, на практиці, самостійно оцінювати свої результати, а також простежувати динаміку успішності та продуктивності навчання в цілому $[5,3]$.

PRES-формула (від англ. Position (позиція) Reason (пояснення) - Explanation or Example (наприклад) - Summary (підсумок) застосовується здебільшого у процесі проведення лекційних занять, у контексті нашого дослідження йдеться про проведення лекційних занять англійською мовою. Під час цього методу використовується формула відповіді (позиція - пояснення (обгрунтування) - приклад - підсумок (висновки) на питання студентів. Таким чином, для застосування цього методу обирається такий тип лекцій як лекція-пресконференція, тобто викладач веде розповідь у формі відповідей на запитання студентів [13]. Даний метод можна застосовувати 3 метою вивчення викладачем цільової ситуації, оскільки допомагає викладачу отримати потрібну інформацію про рівень знань курсантів, їх інтереси, навчальні потреби, мотивацію до навчання.

Іншим поширеним методом, який застосовується у вищих військових навчальних закладах за кордоном - це метод Тейера. Суть цього методу полягає у тому, що курсанти вивчають матеріал до початку занять, пізніше цей матеріал закріплюється у аудиторії за допомогою комбінації групового навчання та активних завдань, які виконуються в основному із застосуванням візуалізації. Даний метод вимагає від кожного курсанта самостійності, відповідальності за своє навчання, готовності вирішувати поставлені завдання на кожному занятті [18].

Метод “навчання по станціях" залучає студентів до індивідуальної та колективної роботи, стимулює їх когнітивну, творчу та комунікативну діяльність. Суть цього методу полягає у тому, що студенти працюють над матеріалом, який упорядковується у формі станцій. Вони діляться на малі групи, кожна з груп отримує план з кількістю станцій та завдань, які потрібно виконати. 3 метою контролю виконання завдань передбачається звіт в кінці заняття. Перевага цього методу полягає у тому, що він організовує роботу студентів у групах 3 різним рівнем мовної підготовки, розвиває когнітивні, комунікативні та творчі навички [14]. Метод “навчання по станціях” створює невимушену та творчу атмосферу на заняттях, підвищує мотивацію студентів, розвиває їх вміння корегувати власні помилки, планувати роботу 3 мовним матеріалом, тощо. У цьому випадку, викладач виступає в ролі консультанта, у студента зростає автономність, довіра до викладача, все це - запорука успішного розвитку майбутнього фахівця [7].

Стосовно вищих військових навчальних закладів за кордоном, викладачі найчастіше використовують такі засоби навчання: електронні засоби навчання (навчально-методичні комплекси на основі програмної підтримки, програмне забезпечення тощо), технічні засоби навчання (комп'ютери, смарт-дошки, мультимедійні проектори тощо), друковані засоби навчання 


\section{ОРГАНІЗАЦЙНН АСПЕКТИ ФОРМУВАННЯ МГЖКУЛЬТУРНОЇ КОМПЕТЕНТНОСТІ МАЙБУТНІХ ФАХІВЦІВ БОЙОВОГО ТА ОПЕРАТИВНОГОЗАБЕЗПЕЧЕННЯ ЗА КОРДОНОМ}

(посібники, статути, довідники, допоміжний матеріал тощо),наочні засоби (ілюстрації, схеми, муляжі, карти, дошка 3 маркерами тощо) [3, 292 - 293]. Всі ці засоби навчання сприяють ефективному засвоєнню навчального матеріалу, допомагають виконувати різноманітні тести, завдання зі студентами [12].

Висновки даного дослідження і перспективи подалыших досліджень. Охарактеризувавши форми організації, методи та засоби навчання за кордоном, можна стверджувати, що вони забезпечують ефективність проведення навчальних занять та допомагають досягти визначених цілей навчання. Коректно підібраний комплекс форм організації навчання,методів та засобів навчання сприятиме, окрім формування професійної компетентності майбутніх фахівців бойового там оперативного забезпечення, ще й ефективному формуванню у них міжкультурної компетентності, що є, як уже було доведено, однією із ключових якостей цих фахівців. Використання викладачами комплексу підібраних методів, форм та засобів навчання має певні переваги, а саме:зацікавленість курсантів та активність у навчанні, самостійна та дослідницька їхня діяльність, співпраця викладача та курсанта, формування у них відповідних знань, умінь та навичок.

Перспективи подальших досліджень полягають у аналізі змістових особливостей формування міжкультурної компетентності майбутніх фахівців бойового та оперативного забезпечення за кордоном.

\section{ЛІТЕРАТУРА}

1. Авдєєнко Ю.В. Застосування кейс методу в процесі професійно-орієнтованого навчання англійській мові у немовних вищих навчальних закладах: матеріали XI Міжнародної науково-практичної конференції (Київ, 21 січня 2016 р.) Київ, 2016. С.1-4.

2. Бойко О.В. Військова педагогіка у професійній діяльності офіцера і сержанта: навч. посіб. Ч.1. Загальні основи педагогіки та військова дидактика. Львів, 2012. $447 \mathrm{c}$.

3. Бойко О.В. Військова педагогіка у професійній діяльності офіцера і сержанта: навч. посіб. Ч.2. Методика та системи виховання військовослужбовців. Львів, 2012.369 с.

4. Військова психологія і педагогіка: підручник, за заг. ред. Л. А. Снігур. Луцьк, 2010. 576 с.

5. Волошко М.О. Тандем-метод как альтернативное средство личностно-профессионального развития преподавателей и студентов языковых вузов и центров дополнительного образования: материалы III всерос. науч.-практ. конф. Тамбов: Бизнес-Наука Общество, 2015. C. $434-440$

6. Гонтарук А.М. Експрес-методи вивчення іноземної мови. Метод Шахтера. Метод Каллана.
Переваги, Недоліки та проблеми застосування. Вісник студентського наукового товариства "ВАТРА" Вінницького торговельно-економічного інституту КНТЕУ. Вінниця, 2019. Вип.67. С. 20-24.

7. Горпініч T.I. Використання методу навчальних станцій для реалізації особистісно-орієнтованого навчання іноземної мови у вищій школі. Молодь $i$ ринок. Щомісячний науково-педагогічний журнал. Дрогобич, 2015. №5. С.46-50.

8. Кравчина Т.В. Тандем-метод як один із способів інтенсивного вивчення іноземної мови та формування іншомовної комунікативної компетенції. Фізикоматематична освіта: науковий журнал. Суми, 2016. № 4(10). С. $45-48$.

9. Курлянд 3.Н.,Хмелюк Р.І.,Семенова А.В. Педагогіка вищої школи: навчальний посібник. Київ: Знання, 2007. 495 с

10. Малафіїк I. В. Дидактика: навчальний посібник. Київ, 2009. 406 с.

11. Микитенко Н.О. Теорія і технології формування іншомовної професійної компетентності у майбутніх фахівців природничих спеціальностей: автореферат дисертації на здобуття наукового ступеня доктора пед. Наук:13.00.04. 13.00.02. Тернопіль, 2011. 43 с.

12. Мова і світ: Сучасні тенденції викладання іноземних мов у вищій школі: матеріали доповідей X Всеукраїнської науково-методичної конференції студентів аспірантів молодих вчених (Кам'янське, 14-15 березня 2017). Дніпро, 2017.

13. Моца А.А. Інноваційні технології навчання у вищій військовій освіті України: практичне застосування. Міжнародний науковий журнал “Інтернаука". 2017. № 5. С. 26-34.

14. Присяжнюк I.C. Використання методу навчання по станціях на заняттях 3 іноземної мови. Сучасні підходи та інноваційні тенденції у викладанні іноземних мов: матеріали XI Міжнародної науково-практичної конференції. (24 березня 2016, Київ). Київ, 2016. 136 с.

15. “Сучасна україністика: наукові парадигми мови, історії, філософії”: матеріали доповідей Міжнародної наукової конференції (Харків, 16-18 квітня 2008 р.). Харків, 2008. С.54-57.

16. Фіцула М.М. Педагогіка: навчальний посібник. Київ, 2003. 528 с.

17. Хамула Л.А. Зарождение и становление военного образования в США: первая половина XIX века. Культурная жизнь Юга России. № (40), 2011.

18. Чайка, В М. Основи дидактики: навчальний посібник. Київ, 2011.238 с.

19. Чорна І.Ю. Формування майбутніх маркетологів англомовної лексичної компетентності в письмі засобом кейс-технології. автореферат дисертації на здобуття наукового ступеня доктора пед.наук: 13.00.02. Тернопіль, 2017. 23 c.

20. Ягупов В.В. Педагогіка: навчальний посібник. Київ, 2002.560 c.

21. Callan Method Organisation. URL: http:// www.callan.co.uk. - 19.04.2017.

22. United States Military Academy. West point. URL: https://westpoint.edu 


\section{ОРГАНІЗАЦЙНІ АСПЕКТИ ФОРМУВАННЯ МГЖКУЛЬТУРНОЇ КОМПЕТЕНТНОСТІ МАЙБУТНІХ ФАХІВЦІВ БОЙОВОГО ТА ОПЕРАТИВНОГО ЗАБЕЗПЕЧЕННЯ ЗА КОРДОНОМ}

\section{REFERENCES}

1. Avdieienko, Yu.V. (2016). Zastosuvannia keis metodu $\mathrm{v}$ protsesi profesiino-oriientovanoho navchannia anhliiskii movi u nemovnykh vyshchykh navchalnykh zakladakh [Application of the case method in the process of professionally oriented teaching of English in nonlanguage of higher education institutions]. Proceedings of the International Scientific and Practical Conference. Kyiv, pp. 1-4. [in Ukrainian].

2. Boiko, O.V. (2012). Viiskova pedahohika u profesiinii diialnosti ofitsera i serzhanta: navch. posib. Ch.1. Zahalni osnovy pedahohiky ta viiskova dydaktyka [Military pedagogy in the professional activities of an officer and sergeant:Part 1 General Fundamentals of Pedagogy and Military Didactics]. Lviv, 447 p. [in Ukrainian].

3. Bojko, O.V. (2012). Viiskova pedahohika u profesiinii diialnosti ofitsera $i$ serzhanta: navch. posib. Ch.2. Metodyka ta systemy vykhovannia viiskovosluzhbovtsiv [Military pedagogy in the professional activities of an officer and sergeant: Part 2 Methodology and systems of training of servicemen]. Lviv,369 p. [in Ukrainian].

4. Viiskova psykholohiia i pedahohika. L.A. Snigur (2010). [Military Psychology and Pedagogy]. Lutsk,576. [in Ukrainian].

5. Voloshko, M.O.(2015). Tandem-metod kak alternatyvnoe sredstvo lychnostno-professyonalnogo razvytyya prepodavatelej y studentov yazukovuch vuzov y centrov dopolnytelnogo obrazovanyya [Tandem method as an alternative means of personal and professional development of teachers and students of language of higher educational institutions and centers of additional education]. Proceedings of the International Scientific and Practical Conference. Tambov, pp. 434-440. [in Russian].

6. Hontaruk, A.M. (2019). Ekspres-metody vyvchennya inozemnoyi movy. Metod Shakhtera. Metod Kallana. Perevahy, Nedoliky ta problemy zastosuvannia [Express methods of learning a foreign language. Shakhtar's method. Callan method. Advantages, Disadvantages and Application Problems]. Vinnytsia, pp.20-24. [in Ukrainian].

7. Horpinich, T.I. (2015). Vykorystannia metodu navchalnykh stantsii dlia realizatsii osobystisnooriientovanoho navchannia inozemnoi movy u vyshchii shkoli [Use of the method of training stations for the implementation of personally oriented learning of a foreign language in a high school]. "Youth and market". Monthly scientific-pedagogical journal. Drogobych,Vol.5, pp. 4650. [in Ukrainian].

8. Kravchyna, T.V. (2016). Tandem-metod yak odyn iz sposobiv intensyvnoho vyvchennia inozemnoi movy ta formuvannia inshomovnoi komunikatyvnoi kompetentsii [Tandem method as one of the methods of intensive study of a foreign language and the formation of a foreign language communicative competence]. Sumy, volume 4(10). pp. 45-48. [ in Ukrainian].
9. Kurliand, Z.N., Khmeliuk, R.I. \& Semenova, A.V. (2007). Pedahohika vyshchoi shkoly [Pedagogy of high school]. Kyiv, p.495. [in Ukrainian].

10. Malafiik, I. V. (2009). Dydaktyka [Didactics]. Kyiv, p.406. [in Ukrainian].

11. Mykytenko, N.O. (2007). Teoriia i tekhnolohii formuvannia inshomovnoi profesiinoi kompetentnosti u maibutnikh fakhivtsiv pryrodnychykh spetsialnostei [Theory and technology of formation of foreign language of professional competence from future specialists in natural sciences]. Ternopil, p. 43. [in Ukrainian].

12. Mova i svit (2017). Suchasni tendentsii vykladannia inozemnykh mov u vyshchii shkoli [Modern trends in teaching foreign languages at higher education]. Proceedings of the International Scientific and Practical Conference. Kamianske. Dnipro. [in Ukrainian].

13. Motsa, A.A. (2017). Innovatsiini tekhnolohii navchannia u vyshchii viiskovii osviti Ukrainy: praktychne zastosuvannia [Innovative technologies of teaching in higher military education in Ukraine: practical application]. International scientific magazine 'Internet Science' vol. 5. pp. 26-34. [in Ukrainian].

14. Prysiazhniuk, I.S. (2016).Vykorystannia metodu navchannia po stantsiiakh na zaniattiakh z inozemnoi movy. Suchasni pidkhody ta innovatsiini tendentsii u vykladanni inozemnykh mov [Use of the method of training in stations in foreign language lessons. Modern approaches and innovative trends in teaching foreign languages]. Proceedings of the International Scientific and Practical Conference (p.136). Kyiv. [in Ukrainian].

15. "Suchasna ukrainistyka: naukovi paradyhmy movy, istorii, filosofii" (2008). [Modern Ukrainian Studies: Scientific Paradigms of Language, History, Philosophy"]. Proceedings of the International Scientific and Practical Conference (pp. 54-57). Kharkiv. [in Ukrainian].

16. Fitsula, M.M. (2003). Pedahohika [Pedagogy]. Kyiv, p.528. [in Urainian].

17. Khamula, L.A. (2011). Zarozhdenye y stanovlenye voennoho obrazovanyia v SShA: pervaia polovyna XIX veka [The origin and formation of military education in the United States: the first half of the nineteenth century].Cultural life of the South of Russia. vol 2 (40) [in Russian].

18. Chaika, V M. (2011). Osnovy dydaktyky [The basics of didactics]. Kyiv,p.238. [ in Ukrainian].

19. Chorna, I.Yu. (2017). Formuvannia maibutnikh marketolohiv anhlomovnoi leksychnoi kompetentnosti $v$ pysmi zasobom keis-tekhnolohii [Formation of future marketers of English language lexical competence in writing by means of case-technology]. Ternopil, p.23. [ in Ukrainian].

20. Yahupov, V.V. (2002). Pedahohika [Pedagogy]. Kyiv, p. 560. [in Ukrainian].

21. Callan Method Organisation. Available at: http:// www.callan.co.uk. - 19.04.2017.

22. United States Military Academy. West point. Available at: https://westpoint.edu

Стаття надійшла до редакції 19.08.2019 